Bangladesh J. Zool. 42(2): 133-139, 2014

\title{
CYTOTOXICITY OF CERTAIN SEED EXTRACTS AGAINST ARTEMIA FRANSISCANA
}

\author{
Raufun Patoary, Omar Ali Mondal, Wahedul Islam and Ataur Rahman Khan* \\ Institute of Biological Sciences, University of Rajshahi, \\ Rajshahi-6205, Bangladesh
}

\begin{abstract}
The chloroform and methanolic extracts of seed coat and seed kernel of Mucuna pruriens, Terminalia. bellirica, Syzygium cumini and Myristica fragrans were tested against the brine shrimp, Artemia fransiscana nauplii for mortality at $24 \mathrm{~h}$ post exposure. All the test extracts were found to be effective. The toxicity of the chloroform extracts of seed coat could be arranged in the order: T. bellirica > $M$. pruriens $>$ S. cumini $>M$. fragrans. In case of seed kernel extracts (chloroform) the results could be arranged in the following order: $S$. cumini $>M$. fragrans $>T$. bellirica $>M$. pruriens. For methanolic extracts of seed coat and seed kernel the results could be arranged in the following order: $M$. fragrans $>T$. bellirica $>S$. cumini $>M$. pruriens, and T. bellirica $>S$. cumini $>M$. fragrans $>M$. pruriens. The brine shrimp bioassay is a simple, reliable and convenient method for the assessment of bioactivity of medicinal plants and lends support for their use in traditional medicine.
\end{abstract}

Key words: Seed coat and kernel extracts, cytotoxicity, Artemia fransiscana.

\section{INTRODUCTION}

Plants are the natural chemical factories that synthesize innumerable compounds. The plant-derived compounds have been utilized by the humankind from time immemorial in different sectors of life, including public health and pest management. The importance of medicinal plants and traditional health systems in solving the health care problems of the world is gaining increasing attention. Because of this resurgence of interest, the research on plants of medicinal importance is growing phenomenally at the international level, often to the detriment of natural habitats and mother populations in the countries of origin. Most of the developing countries have adopted traditional medical practice as an integral part of their culture. Historically, all medicinal preparations were derived from plants, whether in the simple form of raw plant materials or in the refined form of crude extracts, mixtures, etc. Recent estimates suggest that several thousands of plants have been known with medicinal applications in various cultures (Farnsworth and Soejarto 1991). There is great support provided by bench-top bioassays in discovery of bioactive compounds from plants.

*Deceased. Obituary noted in this volume. 
The extracts of the plants, Mucuna pruriens (Papilionaceae), Terminalia bellirica (Combretaceae), Syzygium cumini (Myrtaceae) and Myristica fragrans (Myristicaceae) have widely been utilized for different medicinal purposes. The seeds of $M$. pruriens have much pharmaceutical value (Rastogi and Mehrotra 1991a, b, Singh et al. 1995, Alluri et al. 2005, Gouveia-Figueira et al. 2014). In case of $T$. bellirica, many pharmaceutical reports are available (Padam et al. 1996, Valsaraj et al. 1997, Bhatnagar et al. 2011). Many worker reported the medicinal value of S. cumini (Chopra et al. 1958, Mahapatra et al. 1985, Ghosh et al. 1985, Chaudhary et al.1990, Stanely and Menon 1997, Stanely et al. 1998 a, b).There are also much information on pharmacology of the seeds of $M$. fragrans (Nishat et al. 2006, Afify et al. 2011).

Various workers investigated these plants giving emphasis mostly on the chemical constituents and their medicinal profile but very few works have been done on their pesticidal importance. Toxicity of oily extracts of seed coats and seed kernels were determined by using brine shrimp lethality bioassay (Persoone 1980; Meyer et al. 1982). In this investigation, cytotoxic activity tests were carried out on the brine shrimp, Artemia fransiscana nauplii to evaluate the efficacy of the seed coat and seed extracts as possible sources of potential secondary metabolites to be used as environment friendly pest control agents.

\section{MATERIAL AND METHODS}

Plant collection and identification: Fresh seeds of $M$. pruriens (alkushi), T. bellirica (bahara), S. cumini (kalojam) and M. fragrans (jayfal) were collected from the Botanical Garden, Rajshahi University and the identification of voucher specimens were confirmed at the Taxonomical Section, Department of Botany, University of Rajshahi, Bangladesh.

Preparation of extract: The seeds were chopped into small pieces, dried under internal shade and powdered using a hand grinder separately. The seed and seed coat powder were extracted with chloroform and methanol (BDH, Pooleg, England) using Soxhlet apparatus according to Feuerhake and Schmutterer (1982). The extracts obtained were stored in a refrigerator at $-20^{\circ} \mathrm{C}$ with proper labeling.

Preparation of simulated seawater: The eggs of shrimps were collected from the Department of Pharmacy, University of Rajshahi, Bangladesh. Since the lethality test involves the culture of brine shrimp nauplii, i.e., the nauplii should be grown in water with salinity similar to that of seawater. Accordingly, a $3.8 \%$ sodium chloride solution was prepared by dissolving $38 \mathrm{gm}$ sodium chloride in $1000 \mathrm{ml}$ distilled water. The $\mathrm{P}^{\mathrm{H}}$ of the brine water was maintained between 8.0 and 9.0 by using $\mathrm{NaHCO}_{3}$. 
Hatching of the brine shrimp eggs: Brine water was taken in a small tank and shrimp eggs $(1.5 \mathrm{gm} / \mathrm{L})$ were added to one side of the perforated tank with a constant oxygen supply. A constant temperature $\left(35 \pm 2^{\circ} \mathrm{C}\right)$, sufficient light and air supply were maintained to give the sufficient aeration. After 48 hours, shrimp nauplii were collected and used for the experiment.

Cytotoxicity test: Preparation and application of doses on A. fransiscana: The chloroform and methanolic extracts of seed coat and kernel of the test plants were applied against the brine shrimp nauplii. For the seed coat and kernel of $M$. pruriens, T. bellirica, S. cumini and M. fragrans samples were initially dissolved in $200 \mu 1$ of pure dimethylsulfoxide (DMSO) to make them hydrophilic. Clean vials were taken for the 10 samples in five concentrations (two vials for each concentration) and 10 vials were also taken for control test. Five milliliter of seawater containing 10 brine shrimp nauplii was kept in each vial. With the help of a micropipette, specific volumes of samples were transferred from the stock solutions to the vials to get final concentrations of 5.0,10.0, 20.0, 40.0 and $80.0 \mathrm{\mu g} / 5 \mathrm{ml}$ of brine, because above this concentration cytotoxicity due to DMSO may arise. In the control vials the same volume of DMSO (as in the sample vials) and $5 \mathrm{ml}$ of seawater were taken and $20 \mu \mathrm{DMSO}$ was added to each vial.

Brine shrimp eggs were hatched in simulated seawater to get nauplii. Test samples were prepared by the addition of the requisite amounts of DMSO for obtaining desired concentrations of the test sample. The nauplii were counted by visual inspection and were taken in vials containing $5 \mathrm{ml}$ of brine water. Then samples of different concentrations were added to the pre-marked vials with the help of a micropipette. The vials were left for 24 hours and then the nauplii were counted again to find out the cytotoxicity of the test agents and compared to the results with positive control.

Collection and analysis of data for cytotoxicity: The test tubes containing the nauplii with the treated brine water were kept on a rack near the window in the laboratory. The recorded mortality was corrected by the Abbott's (1925) formula: $\mathrm{P}_{\mathrm{r}}=\frac{\mathrm{P}_{0}-\mathrm{P}_{\mathrm{c}}}{100-\mathrm{P}_{\mathrm{c}}} \times 100$

Where, $\mathrm{P}_{\mathrm{r}}=$ Corrected mortality $(\%), \mathrm{P}_{\mathrm{o}}=$ Observed mortality $(\%)$, and $\mathrm{P}_{\mathrm{c}}=$ Control mortality $(\%)$.

Mortality data were subjected to statistical analyses according to Finney (1947) and Busvine (1971) by using software developed at the Department of Agricultural and Environmental Science, University of Newcastle- upon -Tyne, U.K. The dose-mortality relationship was expressed as median lethal concentrations $\left(\mathrm{LC}_{50}\right)$. 


\section{RESULTS AND DISCUSSION}

The results of dose-mortality assays of different seed extracts against $A$. fransiscana nauplii are presented in Tables 1-4. From this experiment, it is revealed that each of the test samples showed different mortality rates at different concentrations.

Table 1. Toxicity of seed coat (chloroform) extracts against Artemia fransiscana nauplii.

\begin{tabular}{lcccccc}
\hline Test extract & $\begin{array}{c}\text { Time } \\
\text { exposed }\end{array}$ & $\begin{array}{c}\text { LC50 value } \\
(\mu \mathrm{g} / \mathrm{ml})\end{array}$ & \multicolumn{2}{c}{ 95\% Confidence limits } & Regression equation & $\chi^{2}$ value \\
\cline { 4 - 5 } & & & Lower limit & Upper limit & & \\
\hline M. fragrans & $24 \mathrm{~h}$ & 95.58479 & 42.39236 & 215.511 & $\mathrm{Y}=2.750502+1.135887 \mathrm{X}$ & 1.77241 \\
S. cumini & $24 \mathrm{~h}$ & 88.28874 & 42.93272 & 181.5609 & $\mathrm{Y}=2.604101+1.231251 \mathrm{X}$ & 1.53685 \\
T. bellirica & $24 \mathrm{~h}$ & 64.79947 & 35.06378 & 119.7524 & $\mathrm{Y}=2.816124+1.205515 \mathrm{X}$ & 0.39005 \\
M. pruriens & $24 \mathrm{~h}$ & 79.46446 & 42.78583 & 147.5863 & $\mathrm{Y}=2.439498+1.34751 \mathrm{X}$ & 0.61027 \\
\hline
\end{tabular}

Table 2. Toxicity of seed coat (methanolic) extracts against Artemia fransiscana nauplii.

\begin{tabular}{lcccccc}
\hline Test extract & $\begin{array}{c}\text { Time } \\
\text { exposed }\end{array}$ & $\begin{array}{c}\mathrm{LC}_{50} \text { value } \\
(\mu \mathrm{g} / \mathrm{ml})\end{array}$ & \multicolumn{2}{c}{ 95\% Confidence limits } & Regression equation & $\chi^{2}$ value \\
\cline { 4 - 5 } & & & Lower limit & Upper limit & & \\
\hline M. fragrans & $24 \mathrm{~h}$ & 34.23474 & 24.08017 & 48.6715 & $\mathrm{Y}=2.617475+1.552673 \mathrm{X}$ & 1.17796 \\
S. cumini & $24 \mathrm{~h}$ & 41.12985 & 28.25775 & 59.86555 & $\mathrm{Y}=2.466711+1.569419 \mathrm{X}$ & 5.03311 \\
T. bellirica & $24 \mathrm{~h}$ & 34.28775 & 24.38909 & 48.20393 & $\mathrm{Y}=2.508102+1.62324 \mathrm{X}$ & 0.32606 \\
$M$. pruriens & $24 \mathrm{~h}$ & 47.93552 & 32.12584 & 71.52542 & $\mathrm{Y}=2.331575+1.587727 \mathrm{X}$ & 0.92116 \\
\hline
\end{tabular}

It is evident that different plant seed extracts were found to be lethal to brine shrimp nauplii indicating that the extracts are biologically active. The methanolic extract was more active with lower $\mathrm{LC}_{50}$ values whereas the chloroform extract was less active with higher $\mathrm{LC}_{50}$ values. The Brine shrimp lethality bioassay is a recent development in the bioassay for the bioactive compounds (Chaterjee 1975, Meyer et al. 1982, Alkofahi et al. 1989, Pelcjar et al. 1986, McLaughlin 1993 and Persoone 1980). The brine shrimp assay has advantages of being rapid (24h), inexpensive and simple. It easily utilizes a huge number of organisms for statistical validation and requires no special equipment and needs relatively small amounts of sample. Most of the test extracts showed remarkable dose-mortality effects against the 1- day old nauplii of $A$. fransiscana. According to the degrees of activity of the extracts against the brine shrimp nauplii could be arranged in the order: methanolic extract >chloroform extract.

Our results are in agreement with Similar works with $T$. chebula. Other two species of genus Terminalia viz. T. arjuna and T. bellerica showed promising toxicity profile with 47 and $59 \%$ mortality of $A$. fransiscana at $100 \mu \mathrm{g} / \mathrm{ml}$. The brine shrimp lethality bioassay indicates the cytotoxicity as well as wide range of 
pharmacological activities, e.g. anticancer and antiviral activities of oily extract of Sida rbombifolia (Islam et al. 2000). $\mathrm{LC}_{50}$ values of petroleum ether, chloroform and methanol extracts on A. fransiscana. Leach were recorded as $1.14,1.1$, and $54.9 \mathrm{mg} / 1$ respectively. Chemical analysis revealed the presence of fatty acids, steroids, triterpenoids, alkaloids, phenols, and phenyl propanoids, tannin, and mucilage in the extracts (Uyub et al. 2010).

Table 3. Toxicity of seed kernel (chloroform) extracts against Artemia fransiscana nauplii.

\begin{tabular}{lcccccc}
\hline \multirow{2}{*}{ Test extract } & $\begin{array}{c}\text { Time } \\
\text { exposed }\end{array}$ & $\begin{array}{c}\mathrm{LC}_{50} \text { value } \\
(\mu \mathrm{g} / \mathrm{ml})\end{array}$ & \multicolumn{2}{c}{ 95\% Confidence limits } & Regression equation & $\chi^{2}$ Value \\
\cline { 4 - 5 } & & Lower limit & Upper limit & & \\
\hline M. fragrans & $24 \mathrm{~h}$ & 45.00616 & 29.06815 & 69.68294 & $\mathrm{Y}=2.683566+1.401121 \mathrm{X}$ & 0.32692 \\
S. cumini & $24 \mathrm{~h}$ & 41.92609 & 27.55824 & 63.78479 & $\mathrm{Y}=2.701551+1.416623 \mathrm{X}$ & 0.59163 \\
T. bellirica & $24 \mathrm{~h}$ & 58.82652 & 32.51715 & 106.4225 & $\mathrm{Y}=2.910908+1.180563 \mathrm{X}$ & 0.89138 \\
M. pruriens & $24 \mathrm{~h}$ & 71.83673 & 36.79804 & 140.2389 & $\mathrm{Y}=2.831675+1.168061 \mathrm{X}$ & 0.28685 \\
\hline
\end{tabular}

Table 4. Toxicity of seed kernel (methanolic) extracts against Artemia fransiscana nauplii.

\begin{tabular}{lcccccc}
\hline Test extract & $\begin{array}{c}\text { Time } \\
\text { exposed }\end{array}$ & $\begin{array}{c}\text { LC50 value } \\
(\mu \mathrm{g} / \mathrm{ml})\end{array}$ & \multicolumn{2}{c}{ 95\% Confidence limits } & Regression equation & $\chi^{2}$ Value \\
& & Lower limit & Upper limit & & \\
\hline M. fragrans & $24 \mathrm{~h}$ & 30.21676 & 21.61476 & 42.24208 & $\mathrm{Y}=2.671838+1.572819 \mathrm{X}$ & 0.13132 \\
S. cumini & $24 \mathrm{~h}$ & 28.72247 & 20.76573 & 39.72799 & $\mathrm{Y}=2.634581+1.622125 \mathrm{X}$ & 2.10562 \\
T. bellirica & $24 \mathrm{~h}$ & 26.51602 & 19.22125 & 36.57927 & $\mathrm{Y}=2.723973+1.598886 \mathrm{X}$ & 1.45988 \\
M. pruriens & $24 \mathrm{~h}$ & 33.80515 & 23.37058 & 48.89861 & $\mathrm{Y}=2.747884+1.472951 \mathrm{X}$ & 0.15647 \\
\hline
\end{tabular}

A study on seasonal variation in cytotoxic and antioxidant activities of $T$. bellerica was demonstrated by Bhatnagar et al. (2011). Cytotoxicity screening of selected Indian medicinal plants using brine-shrimp lethality bioassay has been done by Chaitali et al. (2010).

This significant lethality of several plant extracts to brine shrimp is an indicative of the presence of potent cytotoxic components which warrants further investigation. A perusal of the data shows that all test extracts produced significant mortalities against $A$. fransiscana nauplii. However, more comprehensive studies are needed in this line.

Acknowledgements: The authors are very much grateful to the Director, Institute of Biological Sciences, University of Rajshahi, Rajshahi-6205, Bangladesh for laboratory facilities and to Rajshahi University for providing financial support. 


\section{LITERATURE CITED}

ABBOTT, W.S. 1925. A method of computing the effectiveness of an insecticide. J. econ. Ent. 18: 265-267.

AFIFY, A.M.R., EL-BELTAGI, H.S., FAYED, S.A.S. and SHALABY, E. A. 2011. Acaricidal activity of different extracts from Syzygium cumini L. Skeels (Pomposia) against Tetranychus urticae Koch. Asian Pac. J. Trop. Biomed. 1(5): 359-364.

ALKOFAHI, A., RUPPRECHT, J.K., ANDERSON, J.E., MCLAUGHLIN, J., MIKOLAJEZAK, K.L. and BERNARD, A. A. Scott 1989. Searches for pesticides from higher plants. In Insecticides of plant origin. American Chemical Society, Washington, DC. pp 26-43.

ALLURI, V. K., TAYI V. N., RAOA, D. S., MULABAGAL V., HSIN-SHENG T. and GOTTUMUKKALA V. S. 2005. Assessment of Bioactivity of Indian Medicinal Plants Using Brine Shrimp (Artemia salina) Lethality Assay. Int. J. Appl. Sci. Eng. 3(2): 125-134.

BHATNAGAR, S., SAHOO, S., BEHERA, D. R. and MOHAPATRA, A.K. 2011. A study on seasonal variation in cytotoxic and antioxidant activities of Terminalia bellerica. Int. J. of Biomed. \& Adv. Res. 2: 427-434.

BUSVINE, J.R. 1971. A critical review of the techniques for testing insecticides. Commonwealth Agricultural Bureaux, London. 345pp.

CHAITALI H. VED, NIKHIL S. MORE, SONALI S. BHARATE and SANDIP B. BHARATE. 2010. Cytotoxicity screening of selected Indian medicinal plants using brine-shrimp lethality bioassay. Advances in Natural and Applied Sciences, 4(3): 389-395.

CHATTERJEE, K. D. 1975. Parasitology in Relation to Clinical Medicine, $10^{\text {th }}$ ed. Pp. 54-59.

CHAUDHARY, A.K.N., PAL, S., GOMES, A. and BHATTACHARYA, S. 1990. Anti inflammatory and related actions of Syzigium cumini seed extract. Phytotherapy Res 4: 510.http://dx.doi.org/ $10.1002 /$ ptr. 2650040103.

CHOPRA, R.N., CHOPRA, I.C., HANDA, K. L. and KAPUR, L. D. 1958. Indigenous Drugs of India, 2nd ed. Calcutta: p. 686, U. N. Dhar and Sons Pvt. Ltd.

FARNSWORTH, N. R. and SOEJARTO, D. D.1991. Global importance of medicinal

FEUERHAKE, K.J. and SCHMUTTERER, H. 1982. Einfache Verfahren Zur Ge Winnung and Formulating Von Niemsamenextrakten and Deren Wirking auf Varschiedene Schadinsekten. Z. Pftkrankh Pflschutz. 89: 737-747.

FINNEY, D. J. 1947. Probit analysis: a statistical treatment of the sigmoid response curve. Cambridge University Press, London. 333 pp.

GHOSH, K., CHAKRA BORTY, D., CHATTERJEe, G. K., CHAUDhURY, A. K. N. and PAL, M. 1985. Studies on anti-inflammatory and antipyretic activities of Syzigium cumini Linn seeds. IRCS Mel. Sci. Biochem. 13: 340-341.

GOUVEIA-FIGUEIRA, S. C., GOUVEIA, C.A., CARVAlHO, M. J., RODRIGUES , A., NORDING, M. L. and CASTILHO P. C. 2014. Antioxidant capacity, cytotoxicity and antimycobacterial activity of Madeira Archipelago Endemic Helichrysum Dietary and medicinal plants. Antioxidants 3: 713729; doi: 10.3390/antiox3040713

ISLAM, E.M., HAQUE, E.M. and RAHMAN, H.M. 2000. Brine shrimp lethality bioassay of the crude extract and isolated compound from Sida rhombifolia Lnn. J. Biol. Sci. 8: 7-9.

MAHAPATRA, P. K., PAL, M., CHAUDHURI, A.K.N., CHAKRABORTY, D. and BASU, A. 1985. Preliminary studies on glycaemic effect of Syzigium cumini seeds. IRCS Med. Sci. Biochem. 13: 631-632.

MCLAUGHLIN, J.L. 1988. Brine shrimp and crown gall tumors: simple bioassay for the discovery of plant antitumor agents. Proceedings, NIH workshop. Bioassay for discovery of antitumor and antiviral agents from natural sources. Bethesda 18(19): 220. 
MEYER, B.N., FERRIGNI, N.R., PUTNUM, J.E., JACOBSON, L.B., NICHOLLS, D.E. and MCLAUGHLIN, J.L. 1982. Brine shrimp: a convenient bioassay for active plant constituents. Plant Medica 45: 31-34.

NISHAT, S., NAHAR, N., MAMUN, M., MOSIHUZZAMAN, M. and SULTANA, N. 2006. Neolignans Isolated from Seeds of Myristica Fragrans Houtt. Dhaka Univ. J. Pharm. Sci. 54(2): 229-231.

PADAM, S.K., GROVER, I.S. and SINGH, M. 1996. Antimutagenic effects of polyphenols isolated from Terminalia bellecica myroblan in Salmonella typhimurium. Indian J. Exp. Biol. 34, 98-102.

PELCJAR, M.J., CHAN, E.C.S. and KRIEG, N.R. 1986. Microbiology, $5^{\text {th }}$ ed. McGraw Hill Book Company, Newyork. p. 79.

PERSOONE, G. 1980. Proceeding of the International Symposium on Brine shrimp, Artemia salina, Vol. 1-3, Unversal Press, Witteren, Belgium. plants. In: Akerele, O., Heywood, V., and Synge, H. (Eds.), The Conservation of Medicinal Plants. Cambridge University Press, Cambridge. pp. 25-51.

RASTOGI, R. P. and MEHROTRA, B. N. 1991a. Compendium of Indian medicinal plants. Vol. I (19601969). Central Drug Research Institute, Lucknow and Publications and Information Directorate, New Delhi.

RASTOGI, R.P. and MEHROTRA, B.N. 1991b. Compendium of Indian medicinal plants. Vol. I (19701979). Central Drug Research Institute, Lucknow and Publications and Information Directorate, New Delhi.

SINGH, B. M., SRIVASTAVA, V.K., KIDWAI, M.A., GUPTA, V. and GUPTA, R. 1995. Aloe, psoralea and mucuna. P. 515-525. In: KL Chadha and Rajendra Gupta (eds.), Advences in horticulture Vol. 11, Medicinal and aromatic plants. pp. 515-525. Malhotra Pub. House, New Delhi.

STANELY, M.P.P. and MENON, V.P. 1997. Hypolipidaemic effect of Syzigium cumini (Jamun) seeds in alloxan diabetic rats. Med. Sci. Res. 25: 819-821.

STANELY, M. P. P. and MENON, V. P. 1998b. Effect of Syzigium cumini in plasma antioxidants on alloxan-induced diabetes in rats. J. Clin. Biochem. Nutr. 25: 81-86. http://dx.doi.org/10.3164/ jcbn.25.81.

STANELY, M. P. P., MENON, V. P. and PARI, L. 1998a. Hypoglycaemic activity of Syzigium cumini; effect on lipid per oxidation in alloxan diabetic rats. J. Ethnopharmacol. 61:1-7. http:// dx.doi.org/10.1016/S0378-8741 (98)00002-6.

UYUB, A.M., NWACHUKWU, I.N., AZLAN, A.A. and FARIZA, S.S. 2010. In vitro antibacterial activity and cytotoxicity of selected medicinal plant extracts from Penang Island, Malaysia on metronidazole-resistant Helicobacter pylori and some pathogenic bacteria. Ethnobot. Res. Appl. 8: 95-106.

VAlSARAJ, R., PUSHPANGADAN, P., SMITT, U.W., ADSERSEN, A., CHRISTENSEN, S. B., SITTIE, A., NYMAN, U., NIELSEN, C. and OLSEN, C.E. 1997. New anti-HIV-1, antimalarial, and antifungal compounds from Terminalia bellerica. J. Nat. Prod. 60: 739-742.

(Manuscript received on 25 May, 2014; revised on 21 November, 2014) 